\title{
PENGARUH LIKUIDITAS, AKTIVITAS DAN EFISIENSI PENGGUNAAN MODAL KERJA TERHADAP KINERJA KEUANGAN PADA PERUSAHAAN SUB SEKTOR OTOMOTIF YANG TERDAFTAR DI BURSA EFEK INDONESIA PERIODE 20I4-20I8
}

\author{
Alysia Pramesti' \\ Fakultas Ekonomi dan Bisnis Universitas Islam Syekh Yusuf Tangerang \\ Email: 'Alysiapramesty@gmail.com \\ Hadi Suharno² \\ Umi Kulsum ${ }^{3}$ \\ Fakultas Ekonomi dan Bisnis, Universitas Islam Syekh Yusuf Tangerang \\ Email: ${ }^{2}$ hsuharno@unis.ac.id \\ ${ }^{3}$ ukulsum@unis.ac.id
}

\begin{abstract}
This study aims to determine how much influence liquidity, activity, and efficiency of the use of working capital on financial performance. This study includes several independent and dependent variables including: the independent variable is financial performance, while the dependent variable is liquidity, activity, and efficiency of the use of working capital. The population used in this study is a company engaged in the automotive sub sector listed on the Indonesia Stock Exchange during the 2014-2018 period, using a sampling technique in the form of saturated sampling. the number of samples of automotive sub-sector companies that fulfill criteria is 8 companies. Based on partial testing between liquidity (CR) and financial performance (ROA) shows that $t_{\text {count }}(0.250)>t_{\text {table }}$ (I.684). Because the significant value is $0.804>0.05$ which means it is not significant, then $H_{0}$ is rejected $H_{a}$ is accepted. Activity shows that $t_{\text {count }}(-5.002)$ $>t_{\text {table }}$ (1.684). Because a significant value of $0.00<0.05$ which means significant, then $H_{0}$ is accepted $H_{a}$ is rejected. Efficient use of working capital (NWC) shows that $t_{\text {count }}(-0,385)>t_{\text {table }}(I, 684)$. Because the significant value is $0.703>0.05$ which means it is not significant, then $H_{0}$ is is rejected $H_{a}$ accepted. For the results of simultaneous hypothesis testing, namely the $F$ test, the value of $F_{\text {count }}(I 0,53 I)>>F_{\text {table }}(2.87)$ with a significance level of $0.00<0.05$, it can be concluded that liquidity, activity and efficiency of working capital use on financial performance is influential simultaneously on financial performance.
\end{abstract}

Keywords: Liquidity, Activity, Efficiency in Use of Working Capital and Performance Finance

\section{A. PENDAHULUAN}

Perusahaan ini yang bergerak dalam bidang jasa maupun produksi pasti menginginkan agar perusahaan dapat dikelola dengan baik untuk memaksimalkan kesejahteraan perusahaan.Sehingga dapat meningkatkan keuntungan perusahaan.Maka dari itu perusahaan dalam mencapai tujuan harus memperhatikan aktivitas perusahaan yang salah satunya adalah mengelola keuangan perusahaan. Pengelola keuangan itu sendiri dipengaruhi oleh keputusan-keputusan keuangan diantaranya pendanaan dan pembiayaan.

Fenomena yang terjadi, salah satunya sektor industri yang ada di indonesia untuk memenuhi kebutuhan masyarakat dalam berkendara dibidang otomotif dan komponennya di wilayah indonesia. Besarnya minat masyarakat terhadap produk otomotif dapat dilihat dengan semakin meningkatnya permintaan di setiap tahunnya, baik itu produk otomotif kendaraan roda empat dan roda kendaraan roda dua. Sehingga perusahaan otomotif akan di tuntut untuk mengingkatkan produksinya di setiap 
tahun demi memenuhi permintaan konsumen, bahkan setiap perusahaan pasti telah memasang target untuk meningkatkan penjualan di setiap tahunnya. Dengan meningkatnya penjualan disektor industri otomotif, maka sangat berpengaruh sangat besar bagi komponen industri yang ada, hal ini karena penindustrian komponen yang ada di Indonesia untuk saat ini sebagian besar diserap oleh produsen otomotif, sehingga perusahaan otomotif dan komponen yang memiliki keterkaitan sangat erat.

Fenomena yang terjadi, Wakil Presiden lusuf Kalla menyatakan industri otomotif menjadi indikator pertumbuhan ekonomi. Menurut Wapres, semakin maju industri otomotif dan penjualan mobil terus meningkat, dania mengharapkan, industri mobil nasional memberi keuntungan baik kepada masyarakat pengguna, pengusaha, industrinya secara berkesinambungan, membawa kemajuan teknologi, kecepatan logistik, perdagangan, dan meningkatkan pendapatan pemerintah dari sisi pajak. Sementara itu, Ketua Umum Gaikindo Yohannes Nangoi menjelaskan industri otomotif memberi peran besar dalam ekonomi. Memberi dorongan besar pada pasar domestik dan ekspor industri otomotif indonesia. Penjualan otomotif dalam negeri selama 2009 hingga 2015 tumbuh 18,3\%. Tahun lalu, penjualan otomotif sebesar I.0I3.29I juta unit. Sedangkan penjualan semester pertama 2016 sebanyak 531.929 atau naik 1,2\% dari periode yang sama tahun lalu. Sedangkan untuk produksi, pada tahun 2015 sebesar 1.098 .780 unit, semester I 2016 mencapai 60I.46I unit naik 3,8\% dibandingkan periode sama. Sementara itu, ekspor kendaraan jadi tahun 2015 sebanyak 207.69l unit, ekspor kendaraan terurai tahun lalu sebesar 108.770 set, dan kapasitas produksi saat ini sebesar I.928.13I unit setelah adanya investasi dari beberapa perusahaan. Di samping itu, pertumbuhan industri otomotif tersebut rata-rata di atas pertumbuhan ekonomi Indonesia. "Selama ini industri manufaktur berperan penting menjadi tulang punggung perekonomian nasional, karena memberi efek yang luas bagi peningkatan nilai tambah, penyerapan tenaga kerja, penambahan pajak dan cukai, serta penerimaan devisa dari ekspor," sebutnya. Kemperin mencatat, industri pengolahan nonmigas masih menunjukkan kinerja yang positif, di mana pada triwulan II tahun 2018 tumbuh hingga 4,4l\% atau lebih tinggi dibandingkan capaian di periode yang sama tahun lalu sebesar 3,93\%. Bahkan, sektor manufaktur konsisten menja di kontributor terbesar bagi Produk Domestik Bruto (PDB) nasional, yang tercatat di angka 19,83\%. Selanjutnya, industri memberikan kontribusi signifikan terhadap pertumbuhan nilai investasi pada semester I tahun 2018. Jumlah penanaman modal dari kelompok manufaktur mencapai Rp I 22 triliun melalui I0.049 proyek atau menyumbang 33,6\% dari total nilai investasi sebesar Rp 36I,6 triliun. (http://id.beritasatu.com Senin, I Oktober 2018).

Berdasarkan fenomena di atas dapat dijelaskan bahwa peningkatan penjualan industri otomotif ini akan akan meningkatkan kemampuan entitas anak tersebut untuk memperoleh keuntungan di masa yang akan datang, sehingga secara tidak langsung akan memberikan dampak positif terhadap perseroan.

Berdasarkan Peraturan Perundang-undangan Republik Indonesia dalam Financial Ratio kinerja keuangan merupakan penentuan ukuran-ukuran tertentu yang dapat mengukur keberhasilan suatu perusahaan dalam menghasilkan keuntungan.Kinerja keuangan perusahaan yang efisien dapat dilihat dari peningkatan laba yang diperoleh perusahaan. Tujuan mengambil penelitian untuk mengelola dan menyajikan laporan keuangan secara efektif dan efisien agar dapat menjamin laba di perusahaan manufaktur sub sektor otomotif yang terdaftar dibursa efek indonesia. 
Perusahaan yang bergerak dalam bidang manufaktur membutuhkan manajemen kinerja keuangan secara lebih efisien.Hal ini karena aktiva lancar perusahaan menggunakan lebih separuh total aktiva.Dalam penelitian ini rasio likuiditas diwakili oleh current ratio (CR).Alasan peneliti memilih variabel ini adalah untuk mengukur kemampuan perusahaan dalam membayar kewajiban jangka pendek yang jatuh tempo. Jika aktiva lancar mengalami rendah bearti perusahaan akan mengalami kekurangan modal untuk membayar utangnya yang akan segera jatuh tempo. Jika aktiva lancar tinggi belum tentu kondisi perusahaan dalam keadaan baik.

Rasio aktivitas ini digunakan untuk mengetahui tingkat seberapa penggunaan assets perusahaan.Jadi rasio ini dimaksudkan untuk memberikan gambaran seberapa efisien perusahaan dalam menggunakan aset-asetnya untuk menghasilkan penjualan. Semakin besar total assets turn overakan semakin baik, karena hal ini perusahaan dapat mengoptimalkan assetnya dalam volume penjualan. Alasan peneliti memilih variabel ini adalah untuk mengetahui kemampuan perusahaan dalam manajemen aset dalam menghasilkan penjualan yang dapat menambahkan laba perusahaan. Semakin besar perputaran aktiva akan semakin baik untuk perusahaan karena dapat menghasilkan penjualan yang lebih besar. Sehingga variabel ini digunakan untuk menguji pengaruhnya perputaran aktiva terhadap kinerja keuangan yang menunjukkan bahwa semakin besar perputaran total aktiva maka akan semakin besar profit perusahaan yang diperoleh.

Modal kerja merupakan hal yang sangat penting bagi setiap perusahaan. Modal kerja merupakan dana yang diperlukan agar operasi perusahaan dapat berjalan lancar sesuai dengan kebijakan-kebijakan yang telah ditentukan oleh perusahaan demi pencapaian tujuan perusahaan tersebut. Jika salah satu aspek yang akan mempengaruhi penggunaan modal kerja yang berlebihan besarnya jumlah modal kerja menunjukkan adanya dana yang tidak produktif atau tidak efektif dan mengakibatkan kerugian bagi perusahaan. Perusahaan juga akan kehilangan kesempatan untuk memperoleh keuntungan yang seharusnya dapat diperoleh. Alasan peneliti memilih variabel ini adalah untuk mengantisipasi penggunaan modal kerja terhadap kinerja keuangan secara tepat dapat memungkinkan perusahan untuk beroperasi secara efisien serta terhindar dari kekurangan atau kelebihan modal kerja. Sehingga variabel ini digunakan untuk menguji pengaruhnya perputaran modal kerja terhadap kinerja keuangan yang menunjukkan bahwa adanya kelebihan modal kerja yang disebabkan rendahnya perputaran persediaan piutang, atau adamya saldo kas yang terlalu besar maka akan sulit memperoleh keuntungan.

Dari beberapa diatas menyatakan bahwa, kinerja keuangan suatu perusahaan sangat berperan penting terhadap perkembangan perusahaan.Maka dari itu penulis tertarik untuk melakukan penelitian skripsi dengan judul "Pengaruh Likuiditas, Aktivitas, dan Efisiensi Penggunaan Modal Kerja Terhadap Kinerja Keuangan pada Perusahaan Sub Sektor Otomotif Yang Terdaftar di Bursa Efek Indonesia Periode Tahun 2014-2018”.

\section{Identifikasi Masalah}

Berdasarkan latar belakang masalah, maka penulis mengindentifikasi beberapa masalah dalam penelitian sebagai berikut :

I. Kemampuan memenuhi kewajiban jangka panjang maupun jangka pendek belum maksimal karena keuntungan yang diperoleh masih rendah.

2. Besarnya penggunaan aktiva terhadap penjualan bearti perusahaan bekerja secara tidak efisien atau tidak efektif sehingga membuat kemampuan perusahaan sulit dalam memperoleh keuntungan. 
3. Rendahnya penggunaan modal kerja bersih perusahaan bekerja secara tidak efisien sehingga akan menimbulkan risiko kerugian yang tinggi yang berdampak pada perkembangan perusahaan.

4. Kinerja keuangan yang baik akan mengoptimalkan kinerja perusahaan, akan tetapi sangat sulit bagi untuk menentukan kinerja keuangan perusahaan yang lebih ideal.

\section{Tujuan Penelitian}

Berdasarkan rumusan masalah diatas, terdapat tujuan dari penelitian ini adalah sebagai berikut :

1. Untuk mengetahui pengaruh likuiditas dalam menunjang kinerja keuangan pada perusahaan sub sektor otomotif yang terdaftar di Bursa Efek Indonesia tahun 2014-20I8.

2. Untuk mengetahui pengaruh aktivitas dalam menunjang kinerja keuangan pada perusahaan sub sektor otomotif yang terdaftar di Bursa Efek Indonesia tahun 2014-20I8.

3. Untuk mengetahui pengaruh efisiensi penggunaan modal kerja dalam menunjang kinerja keuangan pada perusahaan sub sektor otomotif yang terdaftar di Bursa Efek Indonesia tahun 2014-2018.

4. Untuk mengetahui pengaruh likuiditas, aktivitas, efisiensi penggunaan modal kerja dalam menunjang kinerja keuangan pada perusahaan sub sektor otomotif yang terdaftar di Bursa Efek Indonesia tahun 2014-2018.

\section{Landasan Teori, Kerangka Pemikiran, Dan Hipotesis \\ Kinerja Keuangan}

Menurut Horne dan Wachowicz dalam sri (2014:9) mengemukakan "agar dapat mengevaluasi kondisi keuangan perusahaan dan kinerjanya, analis keuangan perlu melakukan pemeriksaan atas berbagai aspek kesehatan keuangan perusahaan".

\section{Likuiditas}

Pengertian Rasio Likuiditas Menurut Arief dan Edi (2016:57) "Rasio likuiditas adalah rasio yang bertujuan untuk mengukur kemampuan perusahaan dalam memenuhi kewajiban jangka pendeknya".

\section{Aktivitas}

Menurut Hanafi dan Halim (20I4:76), "Rasio aktivitas yaitu mengukur sejauh mana efektivitas manajemen perusahaan dalam mengelola aset-asetnya. Artinya dalam hal ini adalah mengukur kemampuan manajemen perusahaan dalam mengelola persediaan bahan mentah, barang dalam proses, dan barang jadi serta kebijakan manajemen dalam mengelola aktiva lainnya dan kebijakan pemasaran. Rasio aktivitas menganalisis hubungan antara laporan laba-rugi, khususnya penjualan, dengan unsurunsur yang ada pada neraca, khususnya unsur-unsur aktiva.Rasio aktivitas yang mengukur sejauh mana efektifitas penggunaan aset dengan melihat tingkat aktivitas aset”.

\section{Efisiensi Penggunaan Modal Kerja}

Menurut Kasmir (2016:248), “modal kerja merupakaan modal yang digunakaan untuk melakukan kegiatan operasi perusahaan. Modal kerja diartikan sebagai investasi yang ditanamkan dalam aktiva lancar atau aktiva jangka pendek, seperti kas, bank, surat-surat berharga,piutang,persediaan dan aktiva lancar". 


\section{Kerangka Pemikiran}

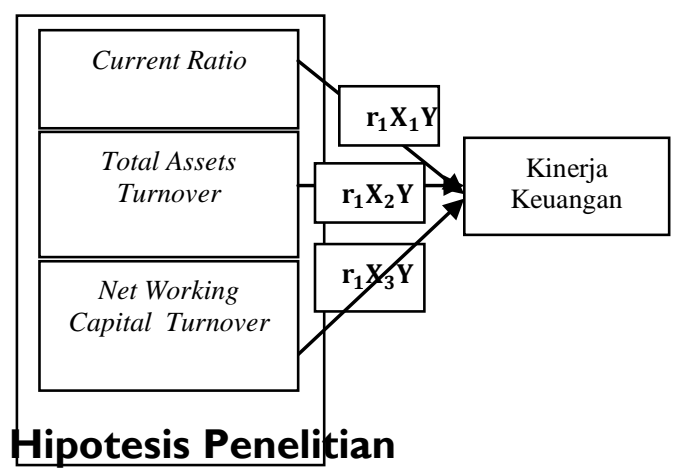

Berdasarkan hasil peneletian terdahulu, maka hipotesis penelitian ini adalah:

$H_{1}$ : Terdapat pengaruh likuiditas terhadap kinerja keuangan.

$\mathrm{H}_{2}$ : Terdapat pengaruh aktivitas terhadap kinerja keuangan.

$\mathrm{H}_{3}$ : Terdapat pengaruh efisiensi penggunaan modal kerja terhadap kinerja keuangan.

$H_{4}$ : Terdapat pengaruh likuiditas, aktivitas dan efisiensi penggunaan modal kerja terhadap kinerja keuangan.

\section{B. METODE PENELITIAN}

\section{Populasi dan Sampel Penelitian}

\section{Populasi}

Menurut Sugiyono (2016:80), mengemukan “populasi merupakan wilayah generalisasi yang terdiri atas objek atau subjek yang mempunyai kualitas dan karakteristik tertentu yang ditetapkan oleh penulis untuk dipelajari dan kemudian ditarik kesimpulannya". Populasi dalam penelitian ini adalah perusahaan manufaktur sub sektor otomotif dan komponen yang terdaftar di Bursa Efek Indonesia (BEI) periode 20I4-20I8 dengan jumlah 8 perusahaan.

\section{Sampel}

Menurut Sugiyono (2016:8I), "Sampel adalah bagian dari jumlah dan karakteristik yang dimiliki oleh populasi tersebut. Teknik dalam pengambilan sampel penelitian menggunakan teknik Sampling Jenuh, yaitu teknik Sampling yang semua anggota populasi digunakan sebagai sampel. Sampling jenuh adalah teknik penentuan sampel bila semua anggota populasi digunakan sebagai sampel. Hal ini sering dilakukan bila jumlah populasi relatif kecil, kurang dari 30, atau penelitian ingin membuat generalisasi dengan kesalahan yang sangat kecil. Istilah lain sampel jenuh adalah sensus, dimana semua populasi dijadikan sampel. (Sugiyono, 2017:85). 


\section{Metode Pengumpulan Data}

\section{Jenis Data}

Untuk keperluan penelitian ini, data yang digunakan yaitu data sekunder. Menurut Sugiyono (2017:193), mengatakan "bahwa data sekunder merupakan sumber yang tidak langsung memberikan data kepada pengumpulan data, misalnya lewat orang lain atau lewat dokumen". Data penelitian diambil dari laporan keuangan tahunan pada perusahaan sub sektor otomotif yang terdaftar di Bursa Efek Indonesia penelitian tahun 2014 sampai dengan 2018. Dan melalui perpustakaan dengan membaca dan mempelajari buku-buku, jurnal-jurnal ilmiah dan literature lainnya yang erat hubungannya dengan objek penelitian.

Teknik pengumpulan data yang digunakan adalah dengan studi pustaka. Penelitian ini dilakukan dengan cara pengumpulan data melalui laporan keuangan perusahaan yang telah dipublikasikan. Penelitian ini juga dilakukan dengan cara mengambil kutipan dari beberapa referensi seperti jurnal, buku dan sumber lainnya dari media elektronik.

\section{Sumber Data}

Sumber data yang dilakukan dalam penelitian ini adalah data sekunder merupakan sumber data yang diperoleh secara tidak langsung yaitu dengan menjelajah situs Bursa Efek Indonesia (BEI) yang dapat diperoleh dengan mengakses www.idx.co.id.

\section{Metode Analisa Data}

Dalam penelitian ini menggunakan metode kuantitatif dengan mengolah serta menganalisis data dibantu program SPSS (statistical Product an Service Solution) versi 25.0.

\section{Uji Asumsi Klasik}

I. Uji Normalitas

Menurut Ghozali (2016:I54) mengemukan bahwa "uji normalitas bertujuan untuk mengetahui apakah masing-masing variabel berdistribusi normal atau tidak." Untuk menguji suatu data distribusi normal atau tidak, dapat diketahui dengan menggunakan grafik normal plot.

2. Uji Multikoloniearitas

Menurut Ghozali (2016:103), "Uji Multikoloniearitas untuk menguji apakah model regresi ditemukan adanya korelasi antara variabel bebas (independen). Model regresi yang baik seharusnya tidak terjadi korelasi antara variabel bebas".

3. Uji Autokorelasi

Menurut Ghozali (2016: 107), ”Uji Autokorelasi bertujuan menguji apakah dalam model regresi linear ada korelasi antara kesalahan pengganggu pada periode $t$ dengan kesalahan pengganggu pada periode t-I (sebelumnya). Jika terjadi autokorelasi maka persamaan tersebut menjadi tidak baik".

4. Uji Heteroskedastisitas

Menurut Ghozali (2016:I34), "Uji Heteroskedastisitas bertujuan menguji apakah dalam model regresi terjadi ketidaksamaan variance dari residual satu pengamatan ke pengamatan yang lain. Jika variance dari residual satu pengamatan ke pengamatan lain, tetap, maka disebut homoskedastisitas dan jika berbeda disebut heteroskedastisitas. Modal regresi yang baik adalah yang homoskedastisitas atau tidak terjadi heteroskedastisitas". Cara untuk mengetahui terjadi heteroskedastisitas atau tidak yaitu dengan melihat Grafik Plot antara nilai prediksi variabel 
dependen yaitu ZPRED dengan residualnya SRESID.Tidak terjadi heteroskedastisitas yaitu apabila tidak ada pola yang jelas, serta titik-titik menyebar di atas dan di bawah angka 0 pada sumbu $Y$.

\section{HASIL PENELITIAN}

\section{Hasil Uji Asumsi Klasik}

\section{a. Uji Normalitas}

\begin{tabular}{|l|l|r|}
\hline \multicolumn{2}{|c|}{ One-Sample Kolmogorov-Smirnov Test } \\
\hline \multicolumn{2}{|c|}{} & Unstandardized Residual \\
\hline Normal Parameters ${ }^{\mathrm{a}, \mathrm{b}}$ & Mean & 40 \\
\cline { 2 - 3 } & $\begin{array}{l}\text { Std. } \\
\text { Deviation }\end{array}$ & .0000000 \\
\hline Most Extreme & Absolute & .128 \\
\cline { 2 - 3 } Differences & Positive & .128 \\
\cline { 2 - 3 } & Negative & $. .1 / 4$ \\
\hline Test Statistic & .128 \\
\hline Asymp. Sig. (2-tailed) & $.094^{\text {c }}$ \\
\hline a. Test distribution is Normal. \\
\hline b. Calculated from data. \\
\hline c. Lilliefors Significance Correction. \\
\hline
\end{tabular}

Sumber: Output SPSS 25, data diolah, 2019

Hasil uji normalitas penelitian dapat diketahui bahwa semua variabel penelitian mempunyai nilai signifikan lebih besar dari 0.05 ( $p>0.05$ ), sehingga dapat disimpulkan bahwa semua variabel penelitian berdistribusi normal.Tabel tersebut menunjukkan bahwa nilai statistik untuk variabel Unstandardized Residual adalah sebesar 0.128, oleh karena itu variabel penelitian mempunyai Asymp. Sig. (2-tailed)0,94 yang lebih besar dari 0.05 maka semua variabel dalam penelitian ini berdistribusi normal. 


\section{b. Uji Multikoloniearitas}

\begin{tabular}{|c|c|c|c|c|c|c|c|c|}
\hline \multicolumn{9}{|c|}{ Coefficients $^{\mathrm{a}}$} \\
\hline \multirow{2}{*}{\multicolumn{2}{|c|}{ Model }} & \multicolumn{2}{|c|}{$\begin{array}{l}\text { Unstandardized } \\
\text { Coefficients }\end{array}$} & \multirow{2}{*}{$\begin{array}{c}\begin{array}{c}\text { Standardized } \\
\text { Coefficients }\end{array} \\
\text { Beta }\end{array}$} & \multirow[b]{2}{*}{$t$} & \multirow[b]{2}{*}{ Sig. } & \multicolumn{2}{|c|}{$\begin{array}{l}\text { Collinearity } \\
\text { Statistics }\end{array}$} \\
\hline & & B & $\begin{array}{l}\text { Std. } \\
\text { Error }\end{array}$ & & & & Tolerance & VIF \\
\hline I & (Constant) & 37.202 & 6.318 & & 5.889 & .000 & & \\
\hline & CR (Likuiditas) & .021 & .084 & .037 & .250 & .804 & .658 & 1.520 \\
\hline & $\begin{array}{l}\text { TATO } \\
\text { (Aktivitas) }\end{array}$ & -.424 & .085 & -.676 & -5.002 & .000 & .810 & 1.234 \\
\hline & $\begin{array}{l}\text { NWC (Efisiensi } \\
\text { Penggunaan } \\
\text { Modal Kerja) }\end{array}$ & $-.09 \mid$ & .237 & -.053 & -.385 & .703 & .782 & 1.279 \\
\hline
\end{tabular}

Sumber: Output SPSS 25, data diolah 2019

Berdasarkan tabel 4.3.2.2 nilai Tolerance variabel likuiditas sebesar $0.658>0.1$, nilai Tolerance variabel Total Assets Turnover sebesar $0.810>0.1$, dan nilai Tolerance variabel Net Working Capital sebesar $0.782>0$.I.Sehingga tidak terdapat multikolonieritas antara variabel independen dalam model regresi tersebut. Sedangkan nilai VIF Likuiditas sebesar I.520< 10, nilai VIF Total Assets Turnover sebesar I.234 < 10, dan nilai VIF Net Working Capital sebesar I.279 < I0. Oleh karena itu dapat disimpulkan bahwa tidak ada multikolonieritas antara variabel independen dalam model regresi tersebut.

\section{c. Uji Heteroskedastisitas}

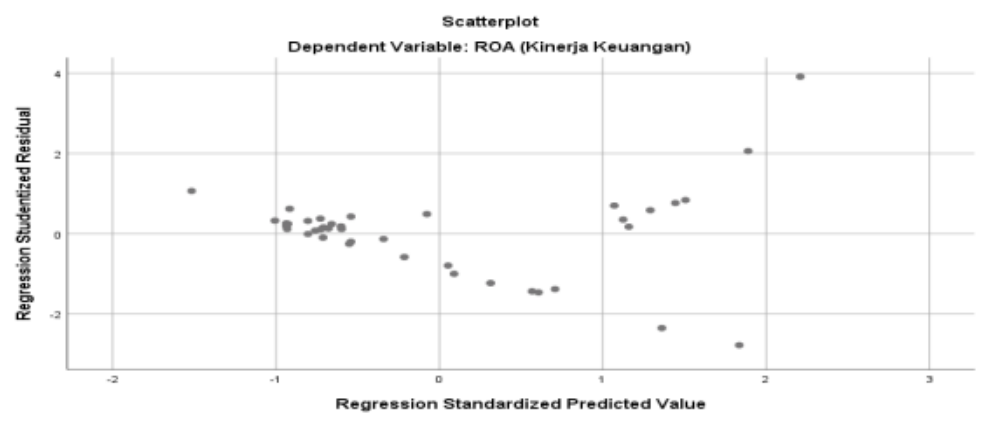

Sumber: Output SPSS 25, data diolah, 2019

Dari gambar di atas terlihat bahwa titik-titik menyebar secara acak diatas maupun di bawah angka 0 pada sumbu $\mathrm{Y}$. Hal ini dapat disimpulkan bahwa tidak terjadi heteroskedastisitas pada model regresi ini, sehingga model regresi layak di pakai untuk variable ROA. Berdasarkan masukan variable independen Likuiditas, Aktivitas, dan Efisiensi Penggunaan Modal Kerja. 


\section{d. Uji Autokorelasi}

\begin{tabular}{|l|c|r|r|r|c|}
\hline \multicolumn{5}{|c|}{ Model Summary } \\
\hline Model & R & R Square & $\begin{array}{c}\text { Adjusted R } \\
\text { Square }\end{array}$ & $\begin{array}{l}\text { Std. Error of } \\
\text { the Estimate }\end{array}$ & $\begin{array}{c}\text { Durbin- } \\
\text { Watson }\end{array}$ \\
\hline I & $.684^{\mathrm{a}}$ & .467 & .423 & 16.06085 & 2.875 \\
\hline $\begin{array}{l}\text { a. Predictors: (Constant), NWC (Efisiensi Penggunaan Modal Kerja), TATO } \\
\text { (Aktivitas), CR (Likuiditas) }\end{array}$ \\
\hline
\end{tabular}

Sumber: Output SPSS 25, data diolah, 2019

Berdasarkan tabel diatas nilai Durbin-Waston sebesar 2.875, nilai Durbin-Watson dibandingkan dengan nilai tabel dengan menggunakan signifikansi $5 \%$ dengan jumlah 3 variabel independen dan I variabel dependen $(k=3)$ dengan jumlah sampel sebanyak $40(n=40)$. Besarnya Durbin-Watson tabel untuk dL (batas luar) $=1.3384$ dan besarnya Durbin-Watson tabel untuk dU $($ batas dalam $)=1.6589$. Besarnya nilai $4-\mathrm{dU}(4-\mathrm{I} .6589=2.34 \mathrm{I} \mathrm{I})$ dan nilai $4-\mathrm{dL}(4-1.3384=$ 2.66I6).

Dari hasil tersebut dapat dilihat bahwa Durbin-Watson2.875 lebih besar dari batas dalam (dU) yaitu 1.6589 dan batas luar (dL) yaitu I.3384 lebih kecil dari Durbin-Watson, jdai dapat jadi dapat disimpulkan bahwa dalam model regresi $\mathrm{H}_{0}$ diterima yang menyatakan bahwa tidak ada autokorelasi positif atau dapat disimpulkan tidak terjadi autokorelasi sehingga persamaan regresi memenuhi syarat.

\section{Uji Hipotesis}

\section{Uji t}

\begin{tabular}{|c|c|c|c|c|c|c|}
\hline \multicolumn{7}{|c|}{ Coefficients $^{a}$} \\
\hline \multirow{2}{*}{\multicolumn{2}{|c|}{ Model }} & \multicolumn{2}{|c|}{ Unstandardized Coefficients } & \multirow{2}{*}{$\begin{array}{c}\text { Standardized } \\
\text { Coefficients } \\
\text { Beta }\end{array}$} & \multirow[b]{2}{*}{$\mathrm{T}$} & \multirow[b]{2}{*}{ Sig. } \\
\hline & & B & Std. Error & & & \\
\hline I & (Constant) & 37.202 & 6.318 & & 5.889 & .000 \\
\hline & CR (Likuiditas) & .021 & .084 & .037 & .250 & .804 \\
\hline & TATO (Aktivitas) & -.424 & .085 & -.676 & -5.002 & .000 \\
\hline & $\begin{array}{l}\text { NWC (Efisiensi } \\
\text { Penggunaan Modal } \\
\text { Kerja) }\end{array}$ & -.091 & 237 & -.053 & -385 & .703 \\
\hline
\end{tabular}

Sumber: Output SPSS 25, data diolah, 2019. 
Dengan $\mathrm{df}=\mathrm{n}-\mathrm{I}=40-\mathrm{I}=39$ dan tingkat kesalahan $\alpha=5 \%$ maka $t_{\text {tabel }}$ diperoleh I.684. Berikut ini adalah hasil pengujian secara parsial yang meliputi likuiditas (CR), aktivitas (TATO), dan efisiensi penggunaan modal kerja (NWC) terhadaap kinerja keuangan (ROA).

I. Pengaruh likuiditas (CR) terhadap kinerja keuangan (ROA)

Pengujian secara parsial antara likuiditas (CR) dengan kinerja keuangan (ROA) menunjukkan bahwa $t_{\text {hitung }}(0.250)>t_{\text {tabel }}$ (1.684).Karena nilai signifikan $0.804>0.05$ yang bearti tidak signifikan, maka $\mathrm{H}_{0}$ ditolak $\mathrm{H}_{a}$ diterima.Artinya terdapat pengaruh positif dan tidak signifikan secara parsial antara likuiditas (CR) dengan kinerja keuangan (ROA).

Alasan tidak signifikan likuiditas (CR) terhadap kinerja keuangan ialah dikarenakan data yang digunakan sebagai sampel merupakan perusahaan-perusahaan sub sektor otomotif terlikuid. Hal ini berarti kemampuan perusahaan dalam memenuhi kewajiban jangka pendeknya dengan aktiva lancar yang dimilikinya menunjukkan tingkat keamanan kreditor jangka pendek atau kemampuan perusahaan dalam membayar hutang-hutangnya.

2. Pengaruh aktivitas (TATO) terhadap kinerja keuangan (ROA)

Pengujian secara parsial antara aktivitas (TATO) dengan kinerja keuangan (ROA) menunjukkan bahwa $t_{\text {hitung }}(-5.002)<t_{\text {tabel }}$ (1.684).Karena nilai signifikan $0.00<0.05$ yang bearti signifikan, maka $\mathrm{H}_{0}$ diterima $\mathrm{H}_{\mathrm{a}}$ ditolak.Artinya terdapat pengaruh positif dan signifikan secara parsial antara aktivitas (TATO) dengan kinerja keuangan (ROA).Alasan signifikan aktivitas (ROA) terhadap kinerja keuangan, Hal ini dikarenakan jika suatu perusahaan memiliki aktiva yang terlalu banyak maka beban bunga perusahaan akan menjadi tinggi dan menyebabkan laba yang diterima rendah. Oleh karena itu diperlukan pengelolaan aktiva perusahaan agar laba yang dihasilkan lebih tinggi dari pada beban bunga.Rasio pengelolaan aktiva digunakan untuk dapat mengukur seberapa efektifnya perusahaan dalam mengelola aktivanya dalam menghasilkan penjualan. Semakin baik perusahaan mengelola aktivanya menjadi penjualan maka laba yang dihasilkan oleh perusahaan akan meningkat.

3. Pengaruh Efisiensi penggunaan modal kerja (NWC) terhadap kinerja keuangan (ROA)

Pengujian secara parsial antara Efisiensi penggunaan modal kerja (NWC) dengan kinerja keuangan (ROA) menunjukkan bahwa $t_{\text {hitung }}(-0,385)<t_{\text {tabel }}$ (1.684).Karena nilai signifikan $0.703>0.05$ yang bearti tidak signifikan, maka $\mathrm{H}_{0}$ diterima $\mathrm{H}_{\mathrm{a}}$ ditolak.Artinya terdapat pengaruh negatif dan tidak signifikan secara parsial antara Efisiensi penggunaan modal kerja (NWC) dengan kinerja keuangan (ROA).Alasan tidak signifikan Efisiensi penggunaan modal kerja (NWC) terhadap kinerja keuangan ini menunjukkan peningkatan net working capital berdampak pada penurunan kinerja perusahaan. 


\section{Uji F}

\begin{tabular}{|c|c|c|c|c|c|c|}
\hline \multicolumn{7}{|c|}{ ANOVA $^{a}$} \\
\hline \multicolumn{2}{|c|}{ Model } & Sum of Squares & df & Mean Square & $\mathrm{F}$ & Sig. \\
\hline \multirow[t]{3}{*}{1} & Regression & $8 \mid 49.374$ & 3 & 2716.458 & 10.531 & $.000^{\mathrm{b}}$ \\
\hline & Residual & 9286.232 & 36 & 257.951 & & \\
\hline & Total & 17435.606 & 39 & & & \\
\hline \multicolumn{7}{|c|}{ a. Dependent Variable: ROA (Kinerja Keuangan) } \\
\hline & $\begin{array}{l}\text { edictors: (C } \\
\text { iditas) }\end{array}$ & NWC (Efisiensi & & lodal Kerja), TA & ivitas), ( & \\
\hline
\end{tabular}

Sumber: Output SPSS 25, data diolah, 2019

Dari uji $\mathrm{F}$ test didapat nilai $F_{\text {hitung }}(10,53 \mathrm{I})>F_{\text {tabel }}(2,87)$ dengan tingkat signifikansi $0.00<0.05$ maka dapat disimpulkan likuiditas, aktivitas dan efisiensi penggunaan modal kerja terhadap kinerja keuangan berpengaruh secara simultan terhadap kinerja keuangan.

\section{Koefisien Determinasi}

\begin{tabular}{|l|c|c|c|c|}
\hline \multicolumn{5}{|c|}{ Model Summary } \\
\hline $\begin{array}{l}\text { Mod } \\
\text { el }\end{array}$ & $\mathrm{R}$ & $\begin{array}{c}\mathrm{R} \\
\text { Square }\end{array}$ & $\begin{array}{l}\text { Adjusted R } \\
\text { Square }\end{array}$ & $\begin{array}{l}\text { Std. Error } \\
\text { of the } \\
\text { Estimate }\end{array}$ \\
\hline $\mathrm{I}$ & $.684^{\mathrm{a}}$ & .467 & .423 & 16.06085 \\
\hline $\begin{array}{l}\text { a. Predictors: (Constant), NWC (Efisiensi } \\
\text { Penggunaan Modal Kerja), TATO (Aktivitas), CR } \\
\text { (Likuiditas) }\end{array}$ \\
\hline
\end{tabular}

Sumber: Output SPSS 25, data diolah, 2019

Hasil ouput spss model summary besarnya Adjusted $R$ Square 0.423 atau sama dengan 42,3\%. Hal ini bearti $42,3 \%$ variabel kinerja keuangan (ROA) dapat dijelaskan oleh variabel independen likuiditas, aktivitas dan efisiensi penggunaan modal kerja. Sedangkan sisanya (100\%42,3\%) 57,7\% dijelaskan oleh sebab-sebab yang lain. Nilai adjusted R Square yang kecil dikarenakan adanya faktor faktor lain yang ikut mempengaruhi variabel. Karena dalam praktiknya faktor faktor seperti makroekonomi, risiko sistematis dan risiko unsistematis, kesehatan dan kinerja keuangan perusahaan juga turut mempengaruhi laba perusahaan. Hasil dari variabel CR (likuiditas), TATO (aktivitas), yang tidak signifikan juga ikut membuat nilai dari adjusted $R$ Square semakin kecil. 


\section{KESIMPULAN}

Berdasarkan hasil analisa dan pembahasan yang telah dijelaskan pada bab sebelumnya, maka disimpulkan dari peneliti adalah:

1. Berdasarkan hasil uji t hipotesis pertama $\left(H_{1}\right)$ diketahui bahwa secara parsial antara likuiditas $(C R)$ yang diproksikan oleh kinerja keuangan (ROA) berpengaruh positif dan signifikan terhadap kinerja keuangan (ROA) hal ini menunjukkan bahwa $t_{\text {hitung }}(0.250)>t_{\text {tabel }}$ (I.684) dimana nilai signifikan $0.804>0.05$ yang bearti tidak signifikan, maka $\mathrm{H}_{0}$ ditolak $\mathrm{H}_{\mathrm{a}}$ diterima.

2. Berdasarkan hasil uji $\mathrm{t}$ hipotesis kedua $\left(\mathrm{H}_{2}\right)$ diketahui bahwa secara parsial antara aktivitas (TATO) yang diproksikan oleh kinerja keuangan (ROA) berpengaruh positif dan signifikan terhadap kinerja keuangan (ROA) hal ini menunjukkan bahwa $t_{\text {hitung }}(-5.002)<t_{\text {tabel }}(\mathrm{I} .684)$ dimana nilai signifikan $0.00<0.05$ yang bearti signifikan, maka $\mathrm{H}_{0}$ diterima $\mathrm{H}_{\mathrm{a}}$ ditolak.

3. Berdasarkan hasil uji t hipotesis ketiga $\left(\mathrm{H}_{3}\right)$ diketahui bahwa secara parsial antara Efisiensi penggunaan modal kerja (NWC) yang diproksikan oleh kinerja keuangan (ROA) berpengaruh negatif dan signifikan terhadap kinerja keuangan (ROA) hal ini menunjukkan bahwa $t_{\text {hitung }}(-0,385)$ $<t_{\text {tabel }}$ (I.684). Karena nilai signifikan $0.703>0.05$ yang bearti tidak signifikan, maka $\mathrm{H}_{0}$ ditolak $\mathrm{H}_{\mathrm{a}}$ diterima.

4. Berdasarkan hasil uji $\mathrm{F}$ hipotesis keempat $\left(\mathrm{H}_{3}\right)$ diketahui bahwa secara secara simultan likuiditas, aktivitas, dan efisiensi penggunaan modal kerja dan Efisiensi penggunaan modal kerja (NWC) yang diproksikan oleh kinerja keuangan (ROA) berpengaruh positif signifikan. Hal ini dibuktikan dengan hasil signifikan $0.00<0.05$ dan nilai $F_{\text {hitung }}(10,53 \mathrm{I})>F_{\text {tabel }}(2,87)$. Maka maka dapat disimpulkan likuiditas, aktivitas dan efisiensi penggunaan modal kerja terhadap kinerja keuangan berpengaruh secara simultan terhadap kinerja keuangan.

\section{Saran}

Bagi perusahaan sub sektor otomotif yang terdaftar di Bursa Efek Indonesia disarankan lebih memperhatikan total assets turnover. Total assets turnover yang tinggi, berarti perubahan harga jual atau satuan produk, perubahan volume produk yang dijual atau dihasilkan penjualan yang diperoleh lebih tinggi dibandingkan total aktiva, dengan penjualan tinggi kemungkinan besar laba setelah bunga dan pajak akan tinggi, maka tentu akan meningkatkan return on asset..

\section{E. DAFTAR PUSTAKA}

Arief dan Edi Untung.(2016). Panduan Praktis Dasar Analisa Laporan Keuangan. Jakarta: PT Gramedia.

Brigham, Eugene F. dan Joel F. Houston. (2017). Dasar-dasar Manajemen Keuangan, Buku dua,Edisi kesebelas, dialih bahasakan oleh Ali Akbar Yulianto. Jakarta: Salemba Empat.

Bursa Efek Indonesia, www.idx.co.id,Di akses pada tanggal I Juni 2017, pukul 19:00.

C.Sipahelut.,S.Murni.,P.V.Rate., Analisis Kinerja Keuangan Pada Perusahaan Sub Sektor Otomotif dan Komponen Yang Terdaftar Di BEl Periode 20 I 4-20I 6.Jurnal EMBA Vol.5 No.3 September 2017.

Dian Pramesti, Anita Wijayanti, dan Siti Nurlaela. (2016). Pengaruh likuiditas, leverage, aktivitas dan firm size terhadap profitabilitas perusahaan Sub Sektor Otomotif dan Komponen di Bursa Efek Indonesia Vol 20 N0.2 hal 810-8I7.

Fahmi, Irham. (2017). Analisis Kinerja Keuangan . Bandung: Alfabeta. 
Fahmi, Irham. (20I8). Pengantar Manajemen Keuangan Teori dan Soal Jawab. Bandung: Alfabeta

Ghozali, imam.(2016). Aplikasi Analisis Multivariate Dengan Program IBM SPSS 2, Edisi Sembilan. Semarang: Universitas Diponegoro.

Henny Anita Siallagan dan Catur Fatchu Ukhriyawati.(20l4). Pengaruh likuiditas, solvabilitas, dan aktivitas terhadap kinerja keuangan pada perusahaan rokok yang terdaftar di bursa efek Indonesia. Vol.5 No.3 September 2014, Hal.4425-4434

Henry. (20I5). Analisis Laporan Keuangan. Jakarta: Bumi Aksara.

http://id.beritasatu.com diakses: Senin, I Oktober 2018.

https://finance.detik.com

James C. Van Horne, dan John M. Wachowicz, Jr. (2014). Prinsip-prinsip Manajemen Keuangan (Fundamentals of Financial Management). Edisi 13 Buku 2. Jakarta: Salemba Empat

Jumingan (2014) Analisis Laporan Keuangan. Jakarta: PT Bumi Aksara.

K.R. Subramanyam dan John J. Wild (2017). Analisis Laporan Keuangan, Edisi Sepuluh, Jakarta, Salemba Empat.

Kasmir (2018) Analisis Laporan Keuangan. Depok: Rajawali Pers.

Kurniasari, Rahmah. 20I4. Analisis Perbandingan Kinerja Keuangan.

Mulyawan, Setia. 2015. Manajemen Keuangan. Bandung: Cv Pustaka Setia.

Munawir.(2014). Analisis Laporan Keuangan. Yogyakarta: Liberty.

Periansya. 2015. Analisa Laporan Keuangan. Palembang: Politeknik Negeri Sriwijaya.

Riyanto, Slamet (20I4). Kupas Tuntas Web Responsif. Jakarta. Penerbit : PT Elex Media Komputindo

Sugiyono (20I5).Metode Penelitian Kuantitatif, Kualitatif dan R\&D. Bandung: Alfabeta.

Sugiyono (2018).Metode Penelitian Kuantitatif, Kualitatif dan R\&D.Bandung: Alfabeta.

Wardiyah, Mia Lasmi (2017). Analisis laporan keuangan. Bandung: Pustaka Setia 